\title{
Accessory minerals in igneous and metamorphic rocks
}

\author{
Igor Broska • Friedrich Finger • Daniel Harlov
}

Published online: 15 October 2011

(C) Springer-Verlag 2011

This issue is devoted to papers on accessory minerals contributed to the Accessory Minerals Session at the 20th General Meeting of the International Mineralogical Association held in Budapest 21-27 August 2010. The themes included in this special issue not only cover many aspects of the mineralogy and crystal chemistry of zircon, monazite, magnetite, beryl, sphene, columbite, and $\mathrm{Nb}$-Ta oxides but also utilize these accessory minerals as a tool for solving a series of very complex geological problems.

Overall the session and this issue cover accessory minerals from a wide range of magmatic and metamorphic rocks. Novák et al. describe the behaviour of beryl during metamorphic induced hydrothermal activity. Here euhedral, gem quality, large, blue beryl crystals, up to $2 \mathrm{~cm}$ in diameter, formed in syntectonic, quartz-calcite veins in lowgrade, metamorphic, Fe-rich host rocks, which are primarily enriched in $\mathrm{Be}$ and $\mathrm{Li}$, and where $\mathrm{CO}_{2}$ was the major agent for Be mobility. In Chudík et al. complex $\mathrm{Nb}-\mathrm{Ta}(-\mathrm{Sn})$ mineral assemblages from a granite, beryl-rich pegmatite are described. Comparison is made with similar mineral assemblages in other pegmatite bodies from the Western

F. Finger $(\bowtie)$

Department of Materials Engineering and Physics,

University of Salzburg,

5020 Salzburg, Austria

e-mail: Friedrich.Finger@sbg.ac.at

\section{Harlov}

Section 3.3 Chemistry and Physics of Earth Materials, Deutsches GeoForschungsZentrum - GFZ, Helmholtz-Zentrum Potsdam, Telegrafenberg,

14473 Potsdam, FR, Germany

\section{Broska}

Slovak Academy of Sciences, Geological Institute,

Dúbravska cesta 9 ,

84005 Bratislava, Slovak Republic
Carpathians in order to link mineralizing potentials between the various occurrences in this region. Colombini et al. deal mainly with sphene stability and saturation in rhyolites from southern Nevada, USA, where they estimate sphene/ melt partition coefficients in conjunction with co-existing zircon saturation and zircon/melt partition coefficients. The results from this study have implications regarding the petrogenesis and geochemical modelling of felsic igneous systems. Krenn et al. present results from monazite dating which they use to constrain the timing of ore mineralization in the eastern Tauern Window, Austria. The results indicate that monazite can occasionally take in large amounts of $\mathrm{S}$ and common $\mathrm{Pb}$, with the latter constituting an appreciable peril for EMPA dating. In Friedl et al. new constraints on Variscan HP-HT metamorphism are determined for granulite facies rocks from the southern Bohemian massif, based on zircon zoning patters. The metamorphic overgrowths of these zircons originated in two evolutionary stages consisting of an inner shell with higher $U$ and an outer shell with lower U. Fluorapatite megacrysts, from the Gloserheia pegmatite, S Norway, which contain xenotime and monazite inclusions are described by Harlov. Formation of these inclusions is interpreted as being due to fluid-aided coupled dissolution-reprecipitation processes sometime during late subsolidus cooling of the pegmatite. Later, fluid-aided Ostwald ripening of these inclusions within the fluorapatite resulted in a scattering of a few large inclusions in areas of the fluorapatite devoid of numerous small inclusions. Broska and Petrik utilize Fe-Ti oxides for the mapping of I-type granite suites. Including pre-mixing and post-mixing Fe-Ti-oxides and their oxidation products in granitoids, this paper demonstrates assimilation processes in granites via common Fe-Ti-oxide, fluorapatite, and titanite assemblages. Burda and Klötzli present cathodoluminescence images and LA-ICP-MS U-Pb analyses of zircons from orthogneiss 
samples taken from the Western Tatra Mountains, Poland. Their data document a previously unrecognized Cadomian (Cambrian) plutonic event in that area and an early Variscan (Devonian) phase of regional metamorphism. Balen and Petrinec describe two types of tourmaline mineralization in peraluminous granites from the Moslavacka Gora Massif, Croatia, and relate these with distinct physico-chemical conditions during granite formation. Carley et al. use zircons as a tool for examining the petrogenesis of silicic volcanic magmas in Iceland. Based on zoning patterns, UTh dating, and elemental compositions of the zircons they are able to document a complex, extended, history of the silicic magmatic systems. Lastly, Bisevac et al. present a study of S-type, Carboniferous granitic pebbles in the Slavonian Mountains, Croatia, including geochemistry, mineral chemistry, and the dating of monazite and micas.
The pebbles document metamorphic reworking during the Cretaceous period and suggest that the Slavonian Mountains experienced a pervasive Cretaceous low-temperature metamorphic event.

This special issue on accessory minerals could not have been accomplished without the hard work of a number of knowledgeable reviewers. The following reviewers are kindly thanked for their help: Havier Rodrigez Aller, Ingo Braun, Bartosz Budzyń, David Dolejs, Scott Ercit, Walli Faryad, Lee A. Groat, John Hanchar, Callum Hetherington, Frantisek Hrouda, Vratislav Hurai, Mike Jercinovic, Jan Kosler, Milan Kohut, Erwin Krenn, Ryszard Kryza, Marieke van Lichtervelde, Jaroslaw Majka, Axel Müller, Daniel Ohnenstetter, Igor Petrik, Franck Poitrasson, Thomas Rainer, Daniela Rubatto, Robert Trumbull, Pavel Uher, Thomas Wenzel, and Gerhard Wörner. 